\title{
微小地震観測網データの自動処理システム
}

\author{
東北大学理学部地震 長谷川昭・海野德仁・山本 明・高木章雄 \\ (昭和 61 年 6 月 8 日受理)
}

\section{Automatic Event Detection and Location System of Microearthquake Observation Network}

\author{
Akira Hasegawa, Norihito Umino, Akira Yamamoto, \\ and Akio TAKAGI \\ Observation Center for Earthquake Prediction, \\ Faculty of Science, Tohoku University
}

(Received June 8, 1986)

An automatic event detection and location system has been developed to process microearthquake data collected by the seismic network of Tohoku University, which covers northeastern Honshu, Japan. The system is composed of three subsystems. The first one (TDE) is a pre-processing system whose main function is event detection. Preliminary hypocenter determination is also made in this pre-processing system. Automatic picking of first arrivals and hypocenter location for events detected by TDE are performed by the second subsystem (RPS). Earthquake hypocenters are located by an iterative method. First, P arrivals are picked and are used to locate the event. Then the system picks $\mathrm{S}$ arrivals by using the expected arrival times from the hypocenter already determined from $\mathrm{P}$ arrivals. Hypocenter location is made again by using both $\mathrm{P}$ and $\mathrm{S}$ arrivals. Subsequently arrivals which do not agree with this location or are missed in the first picking are repicked and the event is relocated. This process is repeated until reasonable result is obtained. In the location procedure included is an algorithm which can remove wrong data or can discriminate two or more events occurred at the same time. The third subsystem (BPS) is a batch processing system for checking the results obtained by RPS.

In June 1984 the system was linked with the telemetering network system of Tohoku University, and since then it has been working in real time. Hypocenter parameters determined from the automatic system are compared to those determined by the manual processing system. It is found that more than $90 \%$ of the events with magnitude larger than 2.0 located in and around the network by manual processing are well located by the automatic system. Differences between hypocenter locations obtained by the automatic and manual processing systems are mostly within a standard deviation of determined hypocenters. Hypocenter distribution obtained from the automatic system clearly shows double-planed deep seismic zone beneath the network, which demonstrates hypocenter locations by the automatic system are quite reliable.

昭和 60 年 11 月 13 日発表 


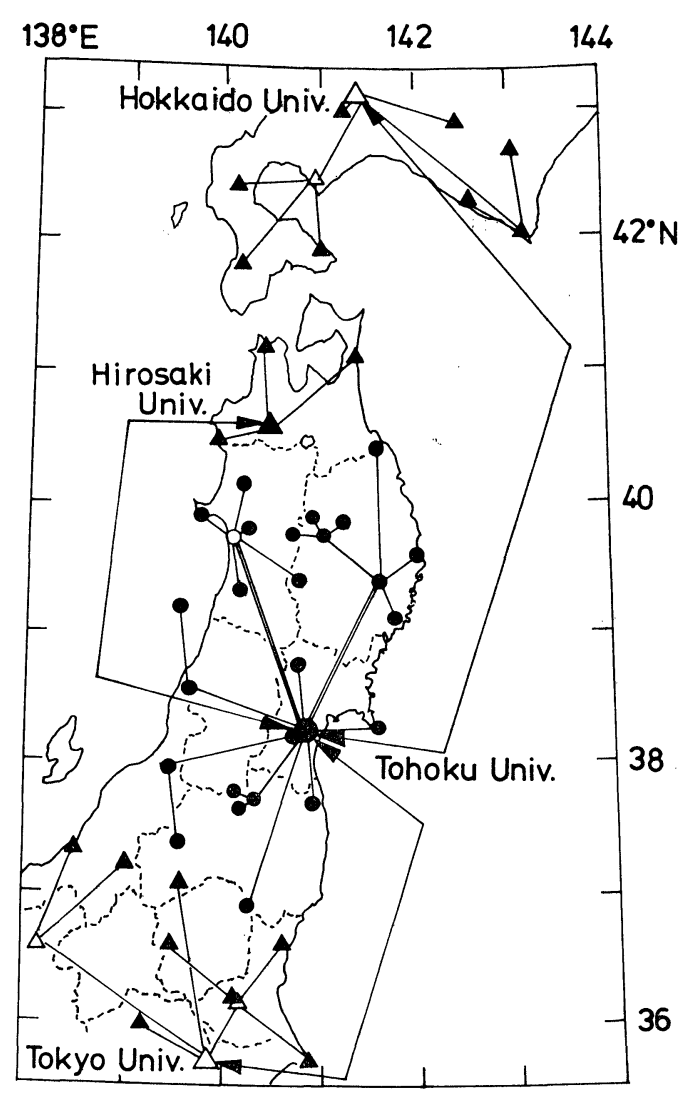

Fig. 1. Map showing locations of stations of the microearthquake observation network of Tohoku University.

\section{§1. はじめに}

東北大学理学部地震予知観測センタ ーでは，テレメータにより集中された 微小地震観測網データを即時自動処理 するため, 昭和 57 年度より地震波自 動処理システムの開発を進めてきた.

このシステムは東北大学観測網と弘前 大学観測網による微小地震データの自 動処理を担当するもので, 験測結果は 東京大学地震研究所内の地震予知観測 情報センターへ実時間伝送される.

東北大学観測網と弘前大学観測網と でほぼ東北地方全域をカバーしている。 これに隣接する東京大学地震研究所お よび北海道大学の観測網から波形デー タの送られてくる観測点を加えると, 観測網の拡がりは南北ほぼ $800 \mathrm{~km}$ に 達する広域となる (Fig. 1). システ ム構築にあたり，この点を充分に考慮 に入れて開発を進めてきた。この処理 システムは昭和 59 年 6 月に稼動態 勢に入り, 同年 7 月には地震予知観測 情報センターへの震源および験測デー タの実時間伝送を開始した. その後り フトウエアの改良をはかり，現在では

ほぼ満足のゆく験測結果が得られるようになつた。

本稿では, この地震波自動処理システムの概要と, それによりどの程度信頼できる処理結果 が得られるかについて報告する。

\section{§2. 地震波自動処理システムの概要}

処理システムは Fig. 2 に示すように, 前処理部 (TDE), 一次処理部 (RPS), 二次処理部 (BPS) の三つのサブシステムにより構成されている. TDE は地震の検出, RPS は TDE で 検出された地震の自動験測, BPS はオフラインの会話処理による再験測の仕事を主として分 担する. 以下に各サブシステムの機能の概要を示す。

\section{2-1. 前処理部 (TDE)}

TDE は, 地震予知観測センターに集中した各観測点の波形信号のとり込み, 地震 の検出 (地震発生・終了の検出), 波形信号の遅延, 各観測点のテレメータ装置の稼動状況の監視等の 機能を分担している.

波形入力信号は，最大アナログ入力 $96 \mathrm{ch，ディジタル入力} 96 \mathrm{ch}$ の合計 $192 \mathrm{ch，サンプ}$ 


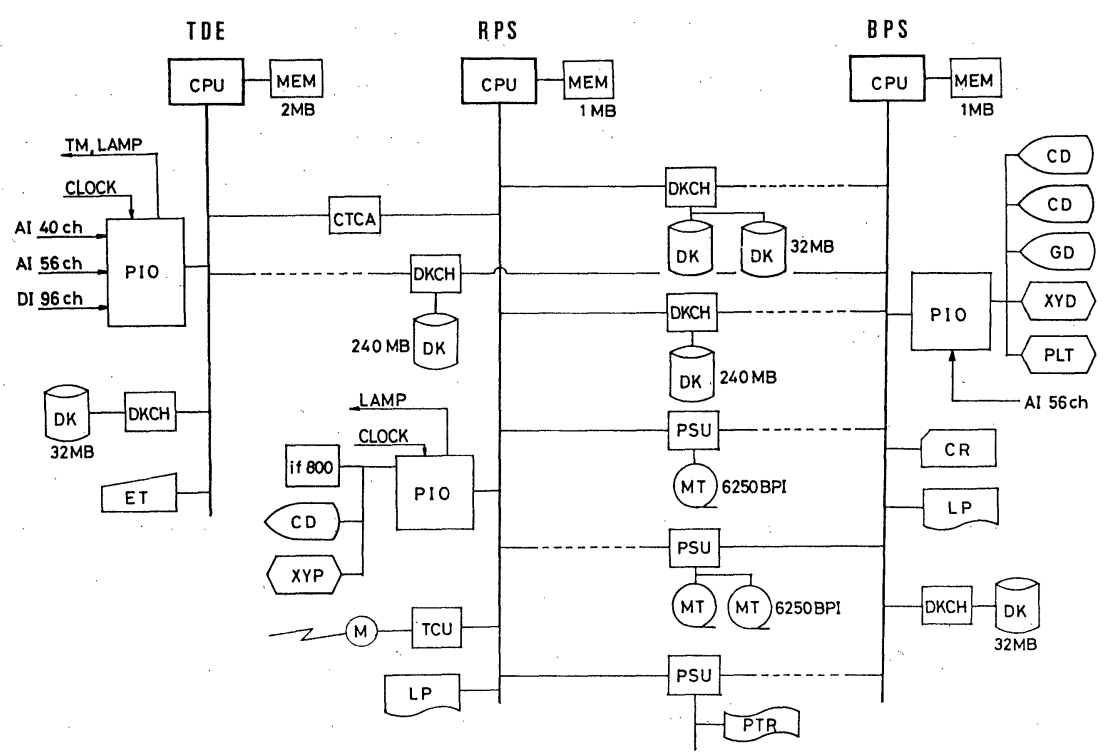

Fig. 2. Block diagram of automatic event detection and location system. Event detection is made by the first processor (TDE). The second processor (RPS) performs phase picking and hypocenter location for events detected by TDE. The third one (BPS) is a batch processor for checking the results obtained automatically by RPS.

リング周波数は $100 \mathrm{~Hz}$ である. 地震の発生・終了の検出には，そのらち各観測点の上下動高 感度成分のみの最大 $60 \mathrm{ch}$ の信号を用いる.これらの上下動成分の信号は, 脈動を除去するた めローカット・フィルターを通した後，その記録振幅情報を用いて各観測点での地震発生の有 無を判別する.この判別（個別トリガー判別）は，具体的には次に示す手順で行われる. 毎回 2 分毎に, ローカット・フィルターを通した上下動成分の信号の絶対值の時間平均を計算し, これからオフセットレベルを除いてノイズレベルとする．このノイズレベルを用いて，P波ト リガーレベルを次のように求める.

$(\mathrm{P}$ 波トリガーレベル $)=C_{1} \times($ ノイズレベル $)+C_{2}$

ここで $C_{1}, C_{2}$ は定数で観測点毎に適正值を設定する．信号がこの $\mathrm{P}$ 波トリガーレベルを， 5 サンプル以上連続してプラス側に越えた時を $\mathrm{S}+$ ， マイナス側に越えた時を $\mathrm{S}$ 一をする．こ の $\mathrm{S}+$ と $\mathrm{S}$ - が交互に発生し, かつそれらが 3 秒以内に 5 回発生した時に, その観測点で地 震を検出したと判定する.この条件により, 回線ノイズ, 雷等によるミストリガーを防ぐこと ができる. そして最初に $\mathrm{P}$ 波トリガーレベルを越えた時刻を, その観測点での $\mathrm{P}$ 波トリガー時 刻とする. 各観測点での地震の終了判定（個別トリガー終了判定）も同様に振幅情報を用いて 行う.

地震か否かの最終判定は, 複数の観測点での $\mathrm{P}$ 波トリガー時刻の組合せで行う（トリガー合 成). 観測点が南北およそ $800 \mathrm{~km}$ に達する広域に分布するため, これらを最大 32 の地域に 分割する. 各々の地域毎にその地域に属する観測点の $\mathrm{P}$ 波トリガー時刻が一定時間内に集中し ているかを調べ，いずれかの地域で判定条件を満足すれば地震と判定する. 
このようにして地震が検出されると, 地震検出信号, 各観測点での $\mathrm{P}$ 波トリガー時刻等の情 報および波形データは, 後段の RPS に転送される.この地震検出信号は, 地震予知観測セン ター，秋田サブセンターおよび北上サブセンターの多チャンネルペン書き記録計にも送られ， トリガー記録がつくられる，その際，ぞの地域で最初に地震が検出されたかにより，出力する 観測点を選ぶようになつている．また地震発生直後に震源情報を知ることができるょう，各観 測点での $\mathrm{P}$ 波トリガー時刻を用いて，P波のみによる即時震源決定を行う．この結果はコンソ ールタイプライターに出力されるので，打执よその震源位置を即座に知ることができる．さら にその地震の終了が検出されると，ただちに S 波到達時刻，振幅，周期，極性等の簡易験測を 実行し，それらを用いて震源およびマグニチュードを決定する．Ｓ波到達時刻は $\mathrm{P}$ 波と同様に 振幅情報を用いて験測する. 得られた震源情報, 各観測点の験測データはコンソールタイプラ イターに出力されるとともに，後段の RPS に転送される. Fig. 3 に TDE での処理の流れ を示す。

\section{2-2. 一次処理部 (RPS)}

RPS では，前段の TDE で検出された地震について，TDE から送られて来た簡易験測結 果を用いて地震か否かの再検討をリアルタイムで行う．地震と判定されるとその終了を待つて， $\mathrm{P}$ 波および $\mathrm{S}$ 波到達時刻，極性，周期，振幅等の自動験測を開始する．RPS での処理の流れ を Fig. 4 に示す. 験測処理の手順は以下の通りである.

TDE から地震検出信号を受け取ると，同じく TDE から受け取つた各観測点での $\mathrm{P}$ 波トリ ガー時刻を用いて，地震か否かの再判定（トリガー合成）を行う. 地震と判定されると，TDE で遅延された波形データを用いて, この地震の「大きさ」を判定し, それを地震発生時刻等の

TDE

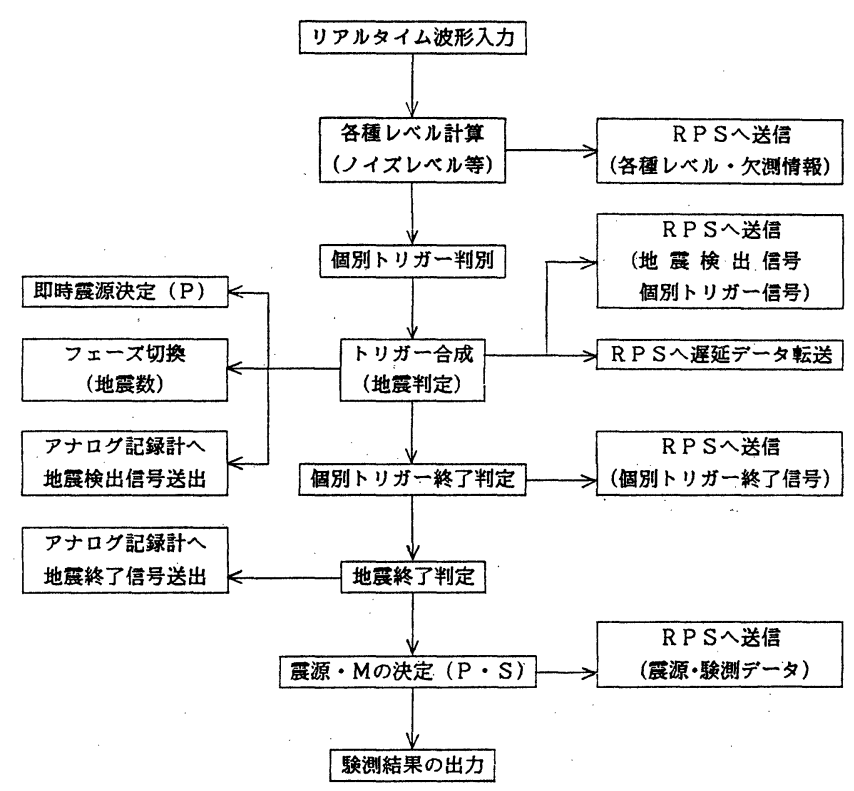

Fig. 3. Software flow chart for TDE subsystem. 
R P S

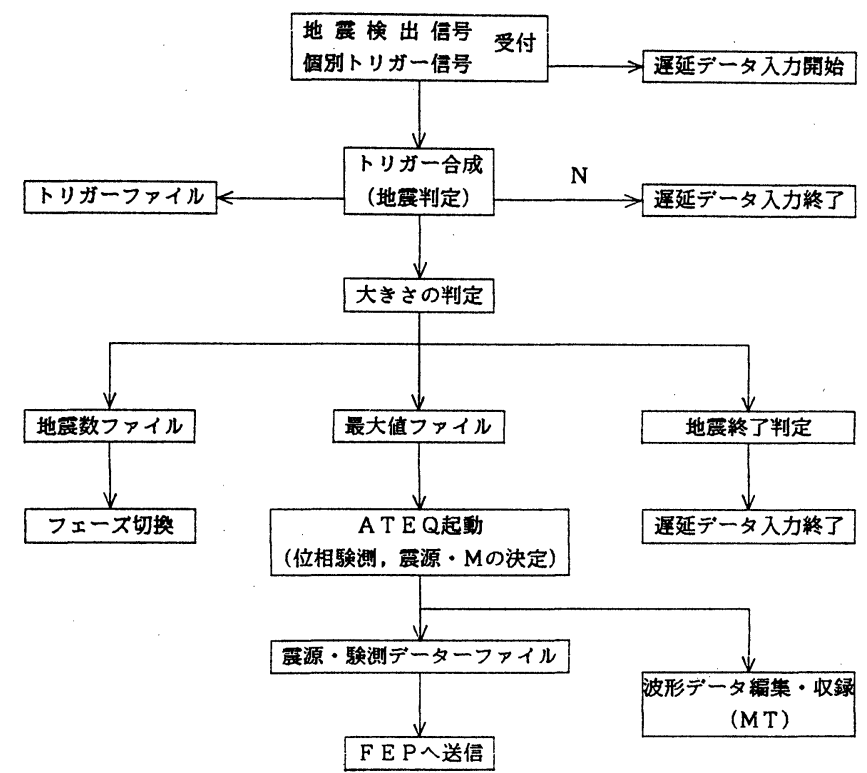

Fig. 4. Software flow chart for RPS subsystem.

情報と一緒に磁気ディスク上のファイル（最大值ファイル）に書き込む．地震の「大きさ」は， 波形振幅の絶対值の一定時間内での平均值で定義する．またこの地震の波形データも磁気ディ スク上のファイル（波形ファイル）に保持される. TDE から次の地震の検出信号が送られて

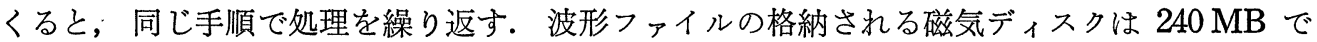
あり，仮に地震が連続して発生しても合計 120 分間の波形データを蓄えることができる．も ちろん，その間次に示すジョブ「ATEQ」が蓄えられた地震を順次に処理するので，大地震が 発生したときの余震活動のように地震が連続して発生しても, 実際には 3 時間程度はもちこた えることができる、しかし，それ以上長時間地震が連続したときには，もはや波形データを蓄 えることができなくなる，そのような場合を想定して，一定時間内に地震数があらかじめ設定 された数を越えたときには，RPS, TDE とも相対的に大きい地震のみを処理するよう設計さ れている.

波形ファイルに蓄えられた個々の地震の験測処理は次のように行われる. 最大值ファイルに 「未処理」の地震があると,「ATEQ」が起動する.これはP波・S 波位相験測, 震源・マグニ チュードの決定等を実行するジョブで, その処理の流れは Fig. 5 に示されている. 未処理の 地震が複数ある場合は, 必ずしも発生時刻順に処理するわけではなく, 大きい地震から先に処 理するよう順番が決められる，処理すべき地震が決をると，その地震の TDE で求められた P波トリガー時刻の前後 10 秒間の波形データを, 各観測点毎に波形ファイルから切り出して くる.この上下動高感度成分の 10 秒間の波形データを用いて，P波位相の読み取りを行う. 位相読み取りの方法については，これまで種々の研究がなされてきたが[例宎ば，ALLEN (1978), 浜口・鈴木 (1979), 市川 (1980), 井白・徳弘 (1979), STEWART (1977), 森田・浜 


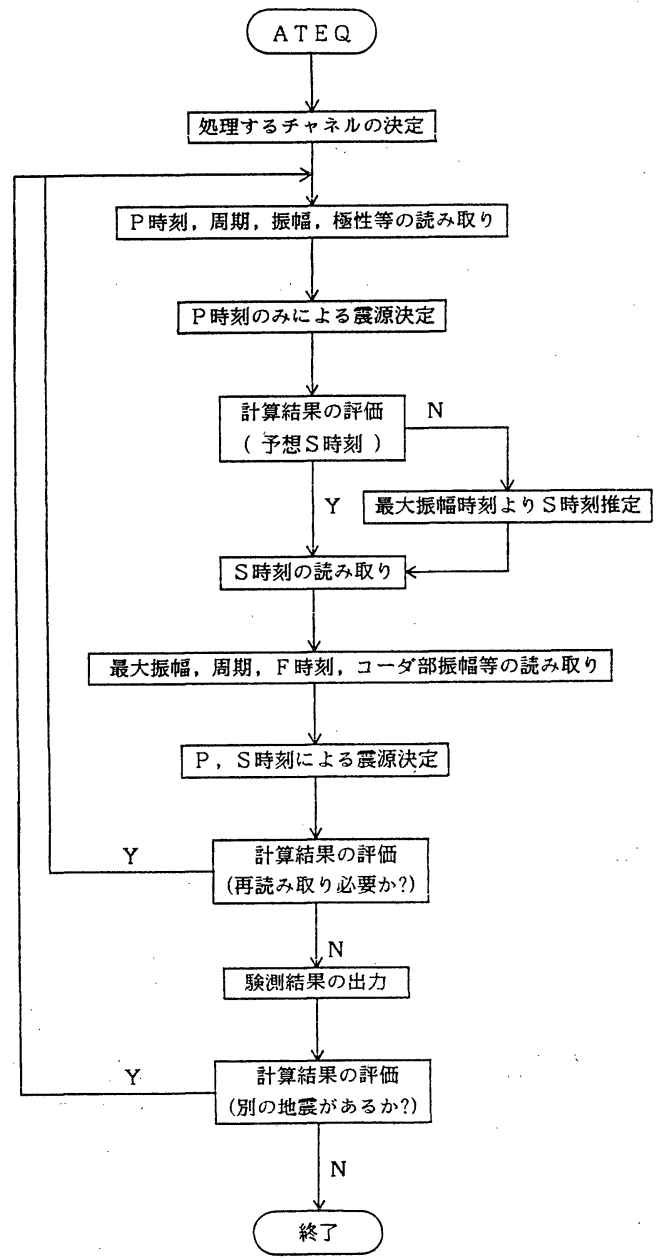

Fig. 5. Flow chart of program ATEQ.
口 (1981), 渡辺 • 他 (1976), 横田 • 他 (1980)], ここでは横田・他にならい赤 池の情報量規準 (AIC) を用いて，位 相を含む時系列の区間を位相混入以降 の区間とそれ以前の区間とに分割する 方法を採る. 読み取り対象区間を二つ に分け，AIC が最小になつたところ をP波到達時刻とするわけであるが， 最小值を与える急峻さをもつて読み取 り精度と考え, それは後述する震源決 定の中で重みとして使われる，P波到 達時刻の自動読み取り結果の例を Fig. 6 に示す。図にはS 波の読又 取 り例も一部含まれている.

各観測点での $\mathrm{P}$ 波到達時刻が読み取 られると， $\mathrm{P}$ 時刻のみを使つて震源決 定を行う. 震源決定法は, 東北大学微 小地震観測網の定常処理に用いている 方法 [HASEGAWA et el. (1978)] であ る.ただし，以下の問題点を解決する ため，後述する論理をつけ加えてある． 自動処理では様々な原因でどうしても 誤った読み取り值が混入してくる場合 が多い。をた観測網の拡がりが南北 $800 \mathrm{~km}$ に達する広域のため，ほぼ同 時刻に複数の地震が別々の地点で発生 する場合が生ずる。このようなとき，

読み取られた全データを使つて震源計算すると，誤つた位置に決まるかあるいは発散してしま う. 単に走時残差の大きい観測点のデータを除いて震源計算を繰り返す方法のみでは, 状況は それ程改善されない，従来，位相読み取りの方法についての研究は多数あるが，このような問 題に関する研究は極めて少ない．異常なデータが混入しているときの推定法としてはロバスト 推定法 [例えば，中川・小柳 (1982)] があるが，それだけでは必ずしも充分ではない。

ここでは人間が験測する場合の手順により近い次のような論理を考えた (Fig. 7). まず全て の $\mathrm{P}$ 時刻読み取りデータのうち，時刻の早い順に三つの観測点を選び出す．この三観測点間の 距離を求め，それが設定された範囲内 $(150 \mathrm{~km})$ であることを確認する.もしどれかの点が上 の条件を満たしてなければ, その観測点のデータを棄却し, 次に早い観測点のデータを取り出 してきて，残つた二点と合わせて同様の作業を繰り返す.このようにして最初の三点が決まる と, 次にこれらの観測点からそれぞれ一定の距離 d (原則的には $100 \mathrm{~km}$ にとり, 観測点密度 の低いところではそれ以上にとつてある）の範囲内の観測点の $\mathrm{P}$ 時刻データを調べる，最初の 


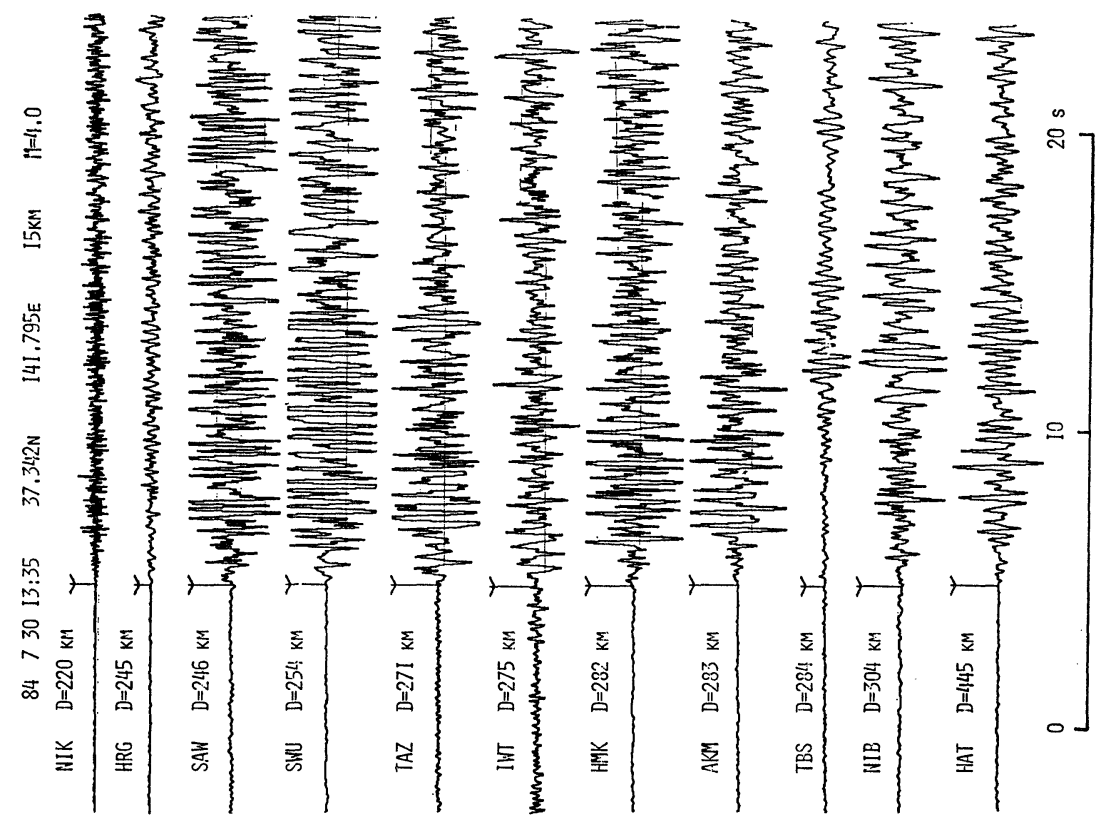

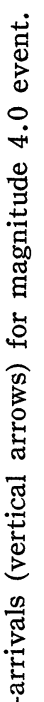

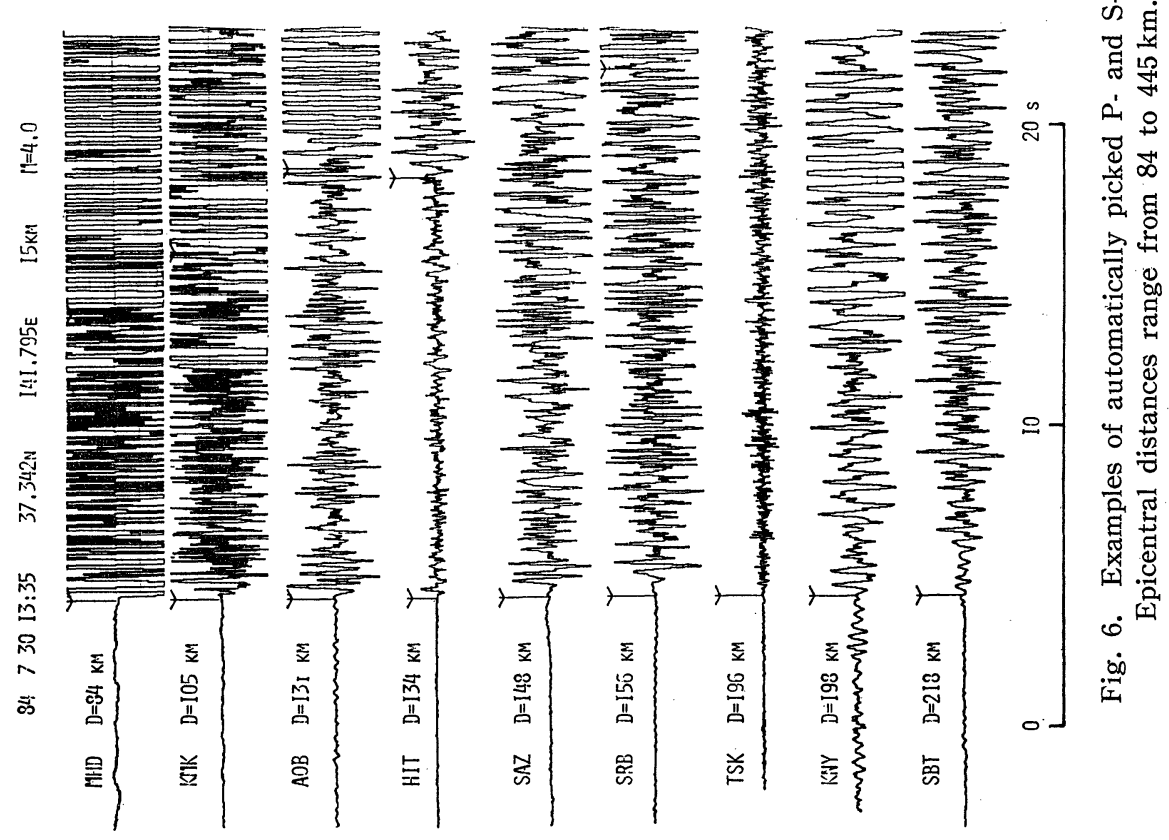



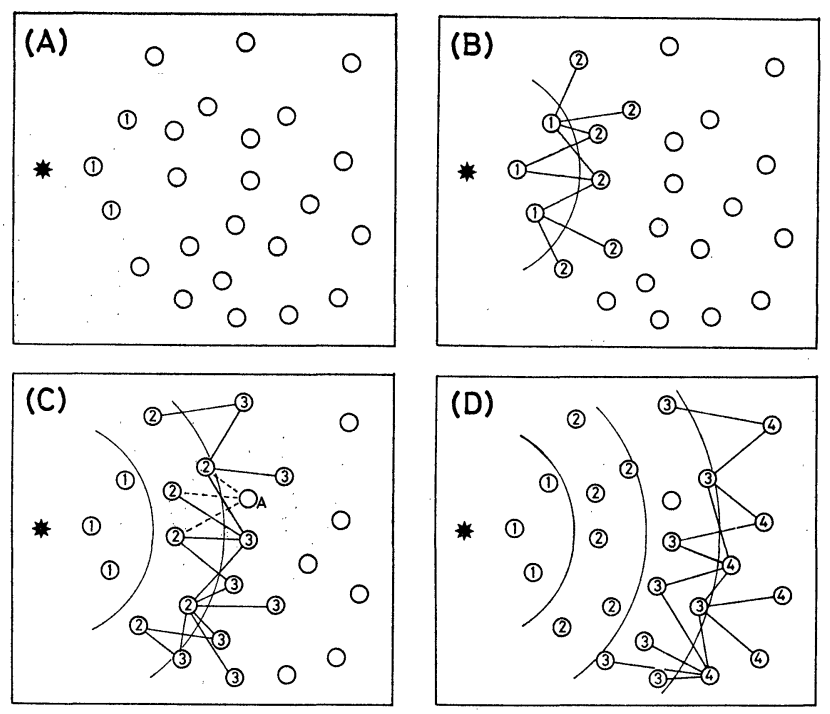

Fig. 7. Schematic representation of proposed algorithm which can remove 'wrong' data from automatically picked $\mathrm{P}$ arrival data set. Star and circles denote locations of epicenter and seismic stations. The algorithm for removing wrong data is based mainly on the value of apparent velocity along the line between two stations (see text for details).

三点を基準にして，それらからいま調べようとする点すでの見掛け速度が決められた值以上の 場合, 当該地震の読み取り值として採用し，そうでない場合はそのデータを棄却する．次に， このようにして選ばれてきた観測点を基準にして上の手順を繰り返す．このような作業を繰り 返すことにより，一つの地震に属するP 時刻データのみを選んでくることができる. Fig. 7 は上記の手順を模式的に示したものである. 次に, このようにして選ばれたデータを用いて震 源を決める. その結果, 走時残差の大きい観測点は除き, また先程棄却されたデータでも走時 残差が小さケれば, 再度データセットの中に取り込み震源計算を繰り返す。さらに，棄却され たデータだけを集めて同様の作業を繰り返せば，ほぼ同時刻に複数の地震が別々の地点で発生 しても，それらをかなり良好に分離することが可能である. 実際にシステムに組み込んだ論理 はもら少し複雑であるが，その概要は以上の通りである.

Fig. 8 に上記の論理でどの程度二つの地震を分離することができるかの例を示す。それぞ れ黒と白の星印の位置に二つの地震が同時刻に発生したとする. 黒の星印の地震 (深さ 10 $\mathrm{km})$ に属する $\mathrm{P}$ 時刻データ数が震央距離の近い順に $N_{1}$ 個, 白の星印の地震 (深さ $30 \mathrm{~km}$ ) に属する $\mathrm{P}$ 時刻デー文数が震央距離の近い順に $N_{2}$ 個とする. いま黒の星印の地震の震 央 と $N_{1}$ (=10) を固定して, $N_{2}$ を 1 から 10 まで, 白の星印の地震の震央を図の位置からもら一 方の地震の震央位置まで変化させる.この二つの地震の $\mathrm{P}$ 時刻データを一緒にして震源決定し た結果が, 綎軸に $N_{2}$, 横軸に二つの地震間の距離をとつて図に示されている. 二つの地震を 正しく分離して決めた場合白丸, 別の位置にきめたり, 発散した場合を黒丸で示す. 単に走時 残差の大きいデータのみを除いて震源決定を繰り返す方法（図のA）では, 全ての場合うまく 分離することができない．前田（1985）と同様にロバスト推定法を用いて震源決定したのが図 


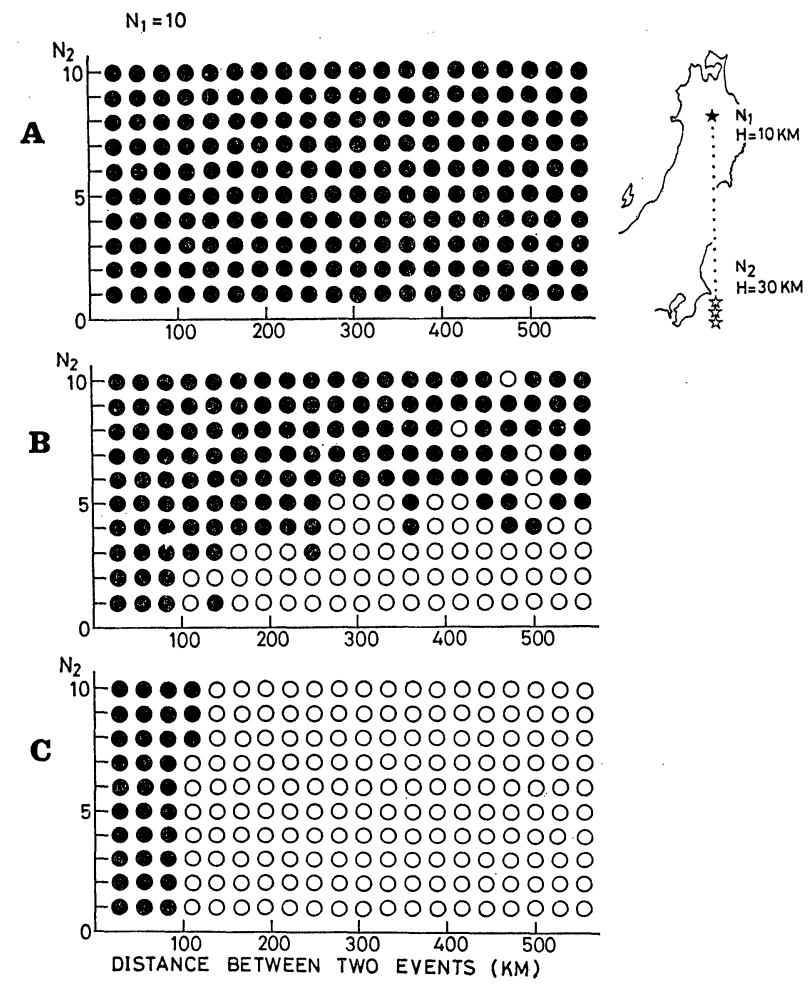

Fig. 8. Results of model calculation of hypocenter location when two events occur simultaneously. Assume an event (solid star) occurs at $10 \mathrm{~km}$ depth and is detected by $N_{1}$ stations. At the same time another event (open star) with focal deph of $30 \mathrm{~km}$ occurs and is detected by $N_{2}$ stations. Model calculation is made by changing $N_{2}$ and epicenter of one event (open star). Open and solid circles indicate the hypocenter is located correctly or not, respectively. (A) Ordinary method cannot discriminate two events and failed in hypocenter location in all the cases. (B) Improvement in the discrimination of two events is made by the robust estimation. (C) Much more improvement is obtained by the presently developed algorithm (see Fig. 7).

のBであり, 結果はある程度改善される.さらに先に述べた論理を組み込むと，飛躍的に改善 される(図のC) ことがわかる.

$\mathrm{P}$ 時刻データのみで震源が決まると， $\mathrm{S}$ 時刻を予測することができる.この推定 $\mathrm{S}$ 時刻の前 後 10 秒間の水平動成分の波形データを波形ファイルから切り出してくる（もしも $\mathrm{P}$ 時刻デー タのみで震源が良く決まらないときは，最大振幅を与える時刻を捜し，そこから前に逆上つて $\mathrm{S}$ 時刻を推定する)． $\mathrm{S}$ 時刻の読み取りも $\mathrm{P}$ 時刻と同様に， AIC による区間分割法で行う．先 に読み取つた $\mathrm{P}$ 時刻データと $\mathrm{S}$ 時刻データを合わせ震源決定する. 決まつた震源位置からみて, 震央距離が近いにもかかわらず読み取られてない観測点があつたり，あるいは読み直すべき観 測点があるような場合，その観測点のデータについて上に述べた手順を繰り返す。このような 作業を繰り返し一つの地震の震源が決められ, その結果はただちにラインプリンタ, 磁気ディ スク上のファイルに出力されるとともに, 東京大学地震研究所内の地震予知観測情報センター 
に伝送される．また波形データは, 震源データ・験測データを加えて記録密度 6250 BPI の MT に収録される.この地震を処理する過程で棄却された $\mathrm{P}$ 時刻データ数が 5 個以上ある場 合，それらのデータだけで同じ作業を繰り返す.

以上が RPS での処理の手順の概要である. $\mathrm{P}$ 時刻, $\mathrm{S}$ 時刻の読み取りの際には, それらの 振幅, 周期, 極性, さらに F-P 時間, コーダ波の各ピークでの振幅およびその時刻等の情報 も読又取られる.

\section{2-3. 二次処理部 (BPS)}

前段の RPS のオンライン処理による験測結果のチェックおよび修正作業を，オフラインの 会話処理によつて行らことができる. 波形データは RPS で収録された MT から磁気ディス クに一旦蓄えられ，そこから必要な部分を切り出してディスプレイの画面に表示される．修正 作業はこの画面上で行われる．MT からディスクに波形データを転送するのに時間がかかる ので, 一つの地震を画面上で処理している間に, 次の地震の波形データを MT からディスク に転送できるようになつている.

BPS はこのようなチェックおよび修正作業の他に種々の処理・解析にも使われる.

\section{§3. 自動処理システムによる験測結果およびその評価}

東北大学では前節に示した手順に従つて，仙台に集中された微小地震観測網データの実時間 自動処理を行つている．この自動処理システムがぞの程度信頼できる験測結果を与えるかを調 ベてみた.

Fig. 9 に東北大学の観測網内およびその周辺で，1985 年 5 月 $15 \sim 22$ 日の 1 週間に，自 動処理システムにより決定された地震の震央（白丸印）を示す．人間による験測結果と比較す るため，図には同一の地震について，人間の験測により決められた震央の位置と実線で結んで ある. Fig. 10 には北緯 $39 \sim 40$ 度の領域に, 自動処理システムにより震源決定された地震 (丸印）の東西鉛直断面を示す. Fig. 9 と同様に，人間の験測により決められた震源位置と実 線で結んである.これらの図から観測網内すなわち陸地の下では, 稍深発地震も含めてて人間の 験測による震源位置と殆ど変わらないことがわかる. 観測網の外に出ると, 特に深さの違いが 大きくなる. 海溝軸の付近では深さの違いが $50 \mathrm{~km}$ を越えるものもある. しかしながら，こ の違いは震源決定精度を考慮に入れるとそれ程大きいものではない，例えば人間による験測結 果でも, 海溝軸付近の地震では観測網から遠く離れているため深さの標準偏差が $50 \mathrm{~km}$ を越 えるものがかなり多数ある.

1985 年 5 月 $15 \sim 22$ 日の期間に, 人間の験測により震源決定された地震のうち, 自動処理 でどの位の割合の地震が決められたかを調べてみた. Fig. 11 にその結果が示されている.人 間の験測により決められた地震のうち，ほぼ 6 割程度の地震は Fig. 9, 10 で示されるような 震源位置の違いで決定されることがわかる，特に観測網内拉よびその周辺に限ると（図中のB の領域), $M \geqq 2$ の地震の場合その $90 \%$ 以上が決定されている.

RPS ではマグニチュードの決定は最大振幅を用いて行われる．高感度成分で飽和した場合 は，それを自動的に検出して，低感度（AOB では超低感度まである）で最大振幅を読むよう になつているのでかなり大きい地震をでそのマグニチュードを決められる、マグニチュード決 定の式は渡辺（1971）による，ただし，各観測点毎にあらかじめ求めてある観測点補正值を加 


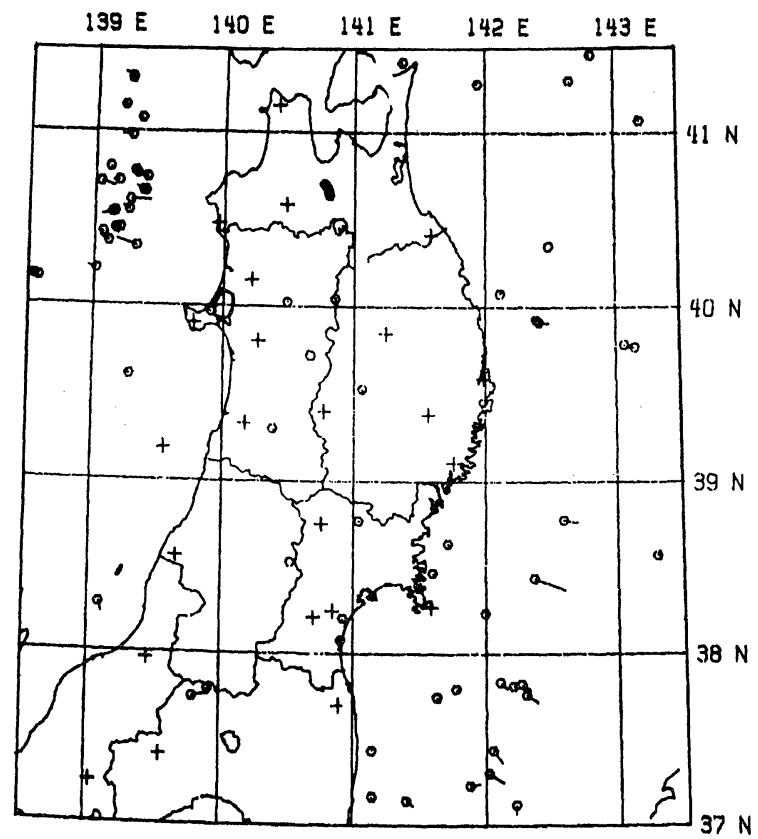

$85.5 .15-5.22$

Fig. 9. Epicenter distribution of earthquakes (open circle) located by the automatic processing system. Differences between epicenter locations by the automatic and manual processing systems are shown by solid line segments. Crosses denote the locations of seismic stations.

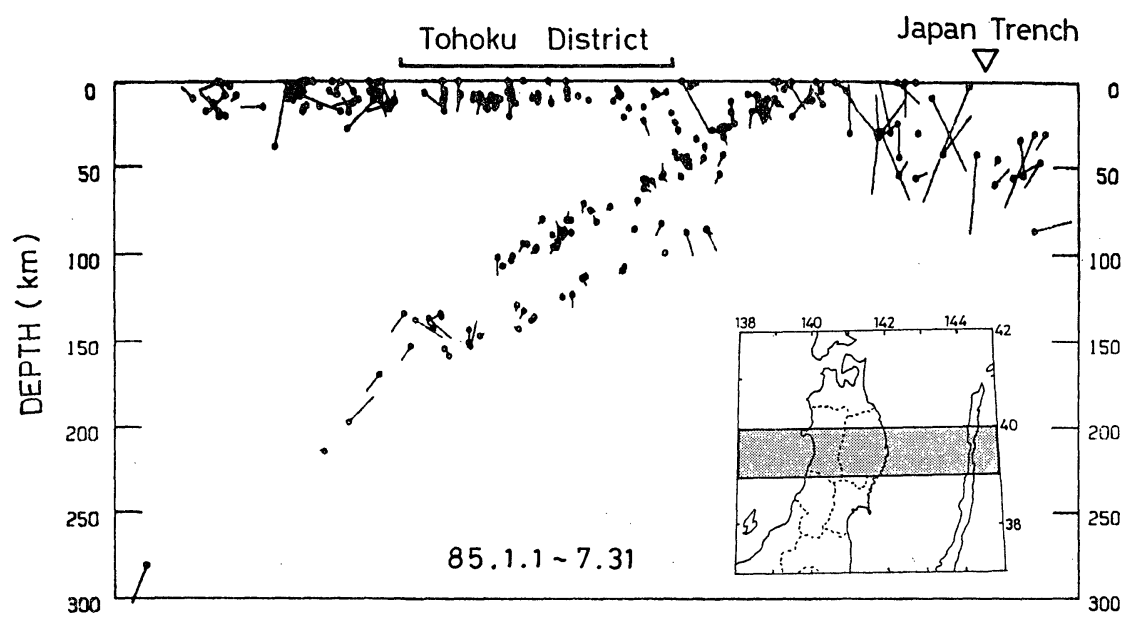

Fig. 10. E-W vertical cross section of earthquakes (circles) located in the region from $39^{\circ} \mathrm{N}$ to $40^{\circ} \mathrm{N}$ (shaded region in the inserted map) by the automatic system. Differences between hypocenter locations by the automatic and manual systems are shown by solid line segments. 


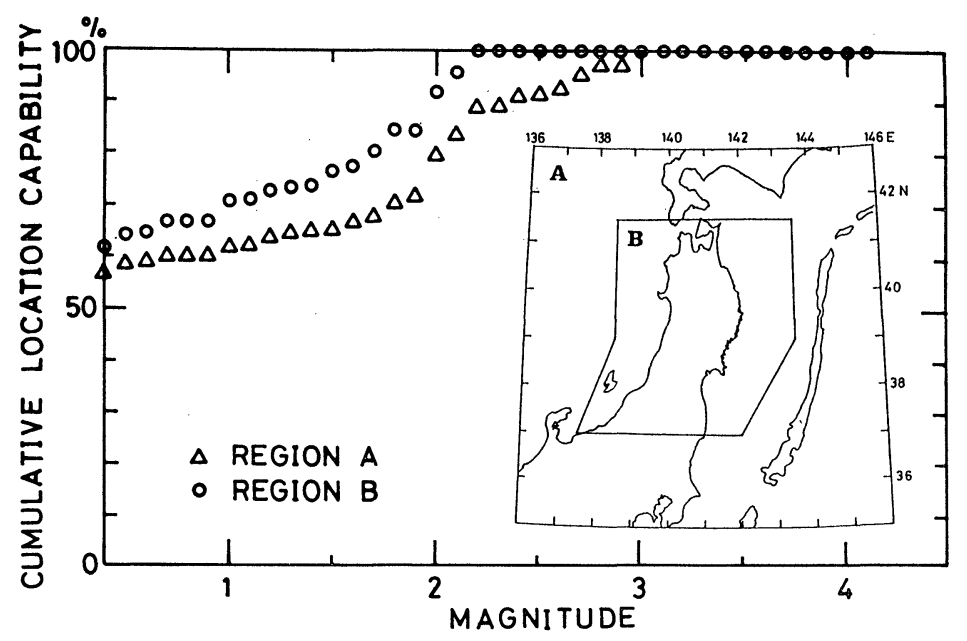

Fig. 11. Cumulative location capability of the automatic system plotted against magnitude. More than $90 \%$ of the events with magnitude larger than 2.0 are well located by the automatic system in and around the seismic network (region $B$ in the inserted map).

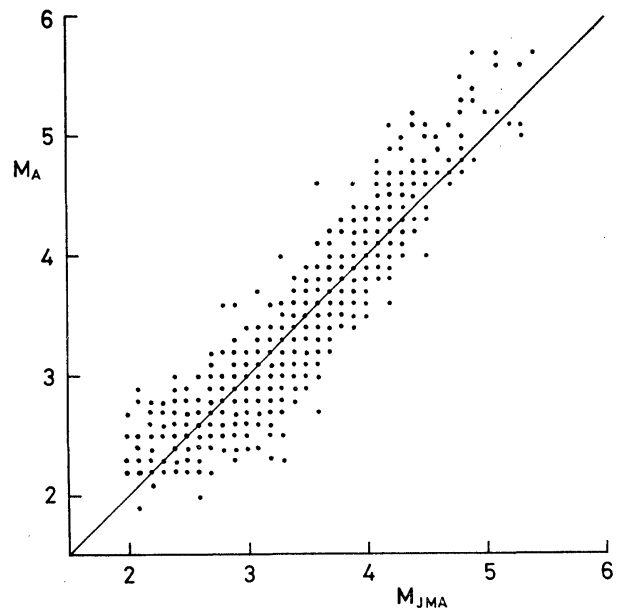

Fig. 12. Comparison of magnitudes determined by the automatic system to those by JMA.
えて計算する. Fig. 12 は自動処理で 決められたマグニチュードと JMA に よるマグニチュードとを比較したもの である. $M \geqq 5$ で自動処理の方がやや 大きめに求めている傾向はあるが，全 体としてはかなり良く一致していると 思われる.

1985 年 $5 \sim 10$ 月の半年間に, 自動 処理で決められた深さ $60 \mathrm{~km}$ 以浅の 地震の震央分布を Fig. 13 に示す. 1983 年日本海中部地震 $(M 7.7)$ の 余震活動, 茨城県沖 - 福島県沖の顕著 な地震活動等, これまで人間の験測に よる定常処理で求められてきた分布図 とそれ程遜色のない結果が得られてい

る. Fig. 14 には 1985 年 3 月 28 日に宮城県鳴子町付近に発生した地震 $(M 4.7)$ とその 余震の震央分布を示す. 自動処理システムにより即時に処理された結果 (B) は, 後で人間に より験測された結果 (A) と較べて，地震数は少ないが分布の傾向はかなり良く一致している. このことは地震活動を常時モニターする上で, 自動処理システムが有効な役割を果たしうるこ とを示している.

Fig. 15 は, 自動処理システムにより決定された地震の鉛直断面である. 図中の $\mathrm{A} \sim \mathrm{F}$ の各 領域に決められた地震の断面を示す. 東北地方の下で既に見出されている [HASEGAWA et al. 


\section{RPS}

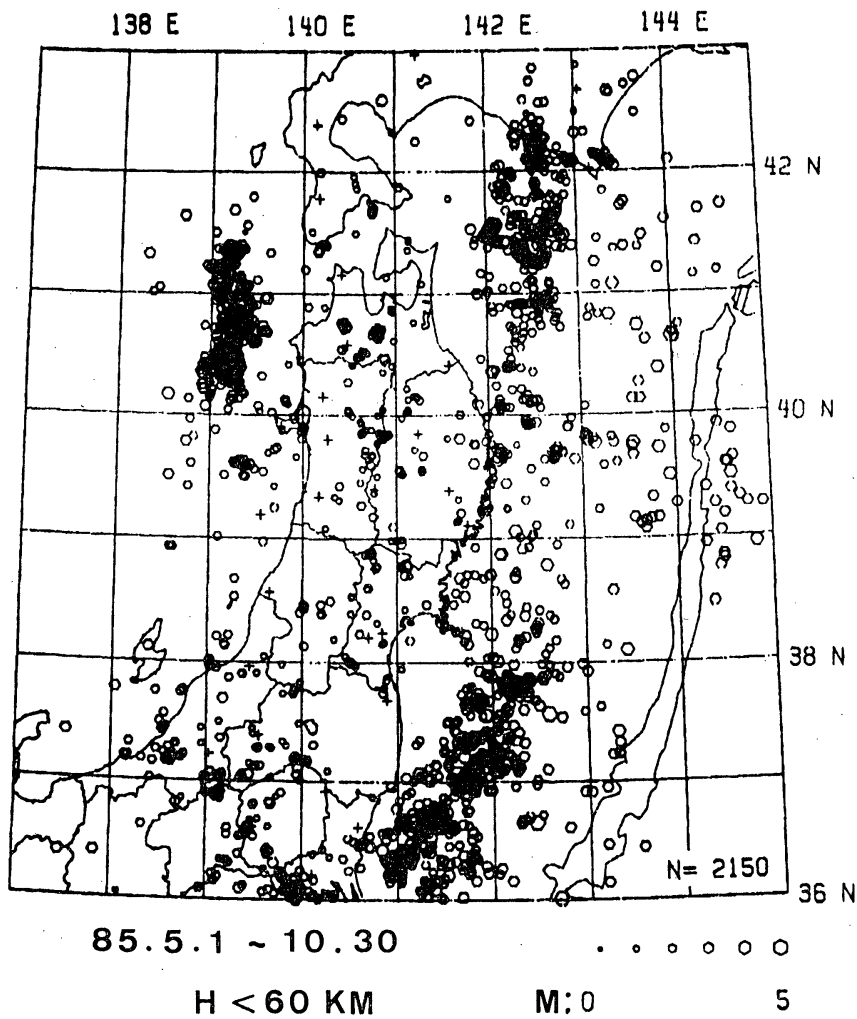

Fig. 13. Epicenter distribution of shallow microearthquakes located by the automatic system for the period from May 1 to October 30, 1985.

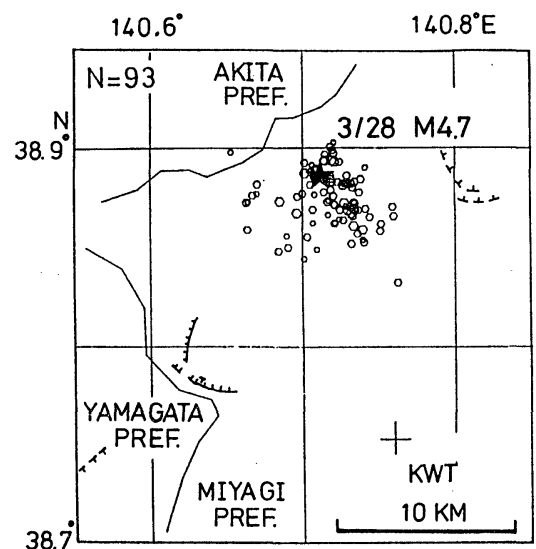

(A)

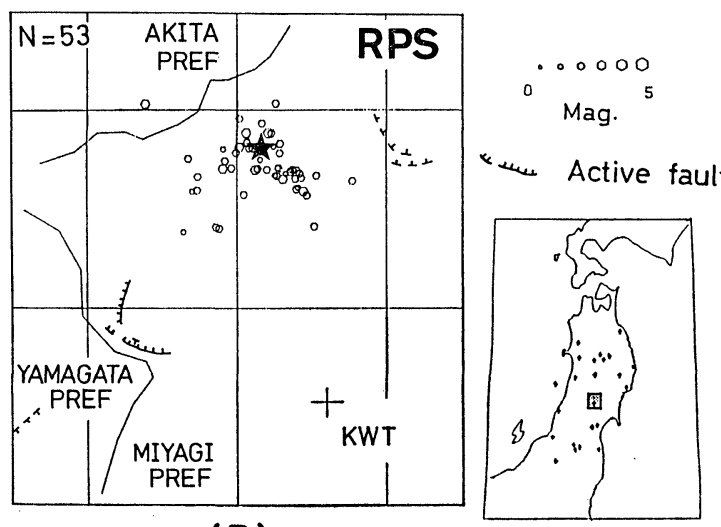

(B)

Fig. 14. Epicenter distribution of $M 4.7$ event (star) and its aftershocks (open circles) occurred near Narugo Town, Miyagi Prefecture. (A) Epicenters located by the manual system, and (B) by the automatic system. 

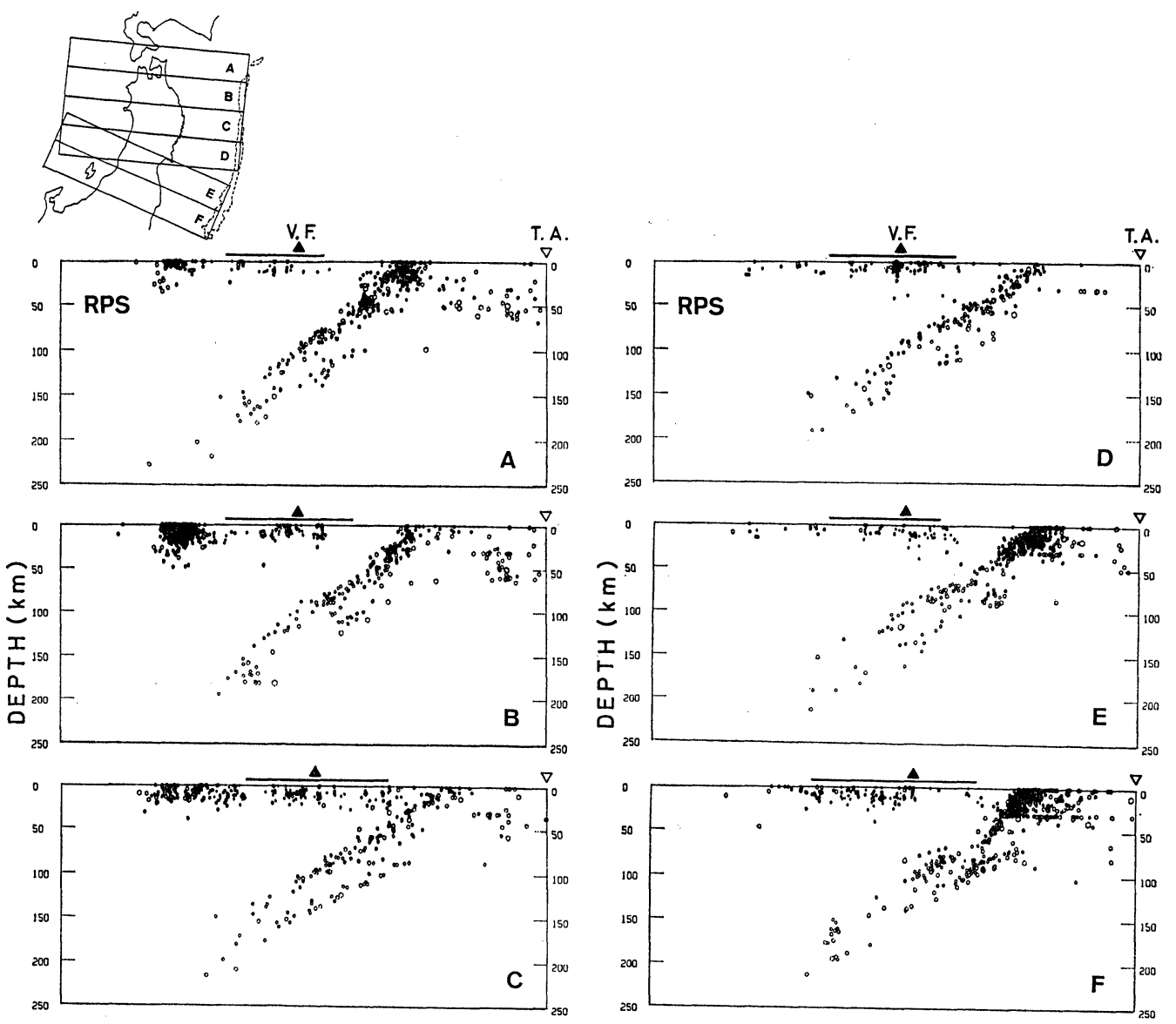

Fig. 15. Vertical cross sections of microearthquakes located by the automatic system for the period from May 1 to October 30, 1985. Horizontal line at the top of each section denotes the land area. Solid triangle and reversed triangle represent the locations of the volcanic front and the trench axis, respectively. Doubleplaned deep seismic zone is clearly seen even from the automatically located hypocenter distribution.

(1978), 海野・他 (1975)] 二重深発地震面が，自動処理による震源分布でも明瞭に認められる. また A， B の断面の日本海下に，1983 年日本海中部地震の余震活動がみられる. その分布を みると東側に向かつて深くなる傾向が認められ，既に得られている結果 [海野・他 (1985)] と 一致している.

\section{§4. おわりに}

東北大学理学部地震予知観測センターに集中された微小地震観測網データの即時自動処理の ための処理システムを開発した.

この処理システムは, 観測点数最大 90 点, 入力チャンネル数最大 192 チャンネルのデー タを処理することができ，昭和 59 年 6 月より稼動態勢に入つている. 得られた験測結果を 
人間による験測結果と比較したところ, 実用上十分な精度で震源決定されていることがわかつ た．例えば，従来東北日本弧で見出されていた二重深発地震面が，この自動処理システムによ る震源分布でも明瞭に認められる.

地震が発生すると即座にその震源が決められるので, 現在当センターでは地震活動の常時把 握の上でこの処理システムが極めて重要な役割を果たしている．そのため個々の地震の処理が 終了するたび毎に, その震源位置が CRT 画面の地図上に重ねて表示されるようになつている. これは，毎日定時にプロッターに出力される過去 1 日間および 5 日間の震源分布図とともに， モニタ一用として役立つている.

\section{謝辞}

本システムの開発にあたり, 東北大学理学部地震予知観測センター, 青葉山地震観測所, 秋 田地殼変動観測所, 本荘地震観測所, 北上地震観測所, 三陸地殼変動観測所の皆様に援助々協 力を頂いた。 またシステムの導入およびシステム開発全般にわたつて，沖電気工業 K.K. の開 発スタッフから援助を賜つた. 深く感謝いたします.

\section{文献}

Allen, R. V., 1978, Automatic Earthquake Recognition and Timing from Signal Trace, Bull. Seism. Soc. Amer., 68, 1521-1532.

浜口博之・鈴木次郎, 1979 , 微小地震 $\mathrm{P}$ 波初動の自動験測とその信頼性について, 自然災害特別研究 成果, No. A-54-2, 62-83.

Hasegawa, A., N. Umino and A. Takagi, 1978, Double-Planed Structure of the Deep Seismic Zone in the Northeastern Japan Arc, Tectonophysics, 47, 43-58.

市川政治, 1980, 地震記録自動処理装置, 験震時報, 44, 55-74.

前田直樹，1985，地震波自動処理システムに拈ける読み取りおよび評価，地震 2, 38, 365-379.

森田裕一・浜口博之, 1981，2 次元自己回帰過程による S 波初動の自動検測, 地震 $2,34,223-240$.

中川 徹・小柳義夫, 1982, 最小二乗法による実験データ解析一プロログラム SALS, 東京大学出版 会.

白井克彦・徳弘一路, 1979, 地震波初動の自動検出, 地震 2, 32, 141-147.

Stewart, S.W., 1977, Real-Time Detection and Location of Seismic Events in Central California, Bull. Seism. Soc. Amer., 67, 433-452.

海野徳仁・長谷川昭，1975，東北日本にみられる深発地震面の二層構造について，地震 2，28，125139.

海野徳仁・長谷川昭・小原一成・松沢 暢・清水 洋・高木章雄・田中和夫・小菅正裕， 1985， 1983 年日本海中部地震の前震と余震の震源分布, 地震 $2,38,399-410$.

渡辺一郎・菅原正己・福井隆文・勝山ヨシ子， 1976，微小地震の自動検出方法について，防狄センタ 一研究報告, 15 号, 33-47.

渡辺 晃, 1971, 近地地震のマグニチュード, 地震 2, 24, 189-200.

横田 崇・周 勝奎・溝上 恵・中村 功, 1981, 地震波データの自動検測方式とオンライン処理シ ステムに打ける稼動実験, 地震研究所彙報, 55, 449-484. 